\title{
BORBOLETAS MUSICAIS
}

\section{Marcelo Rocha Bentes ${ }^{1}$}

Vivendo sobre a face da mesma Terra dos humanos, os animais acabam voluntária ou involuntariamente absorvendo coisas, gestos e gostos dos humanos, e vice-versa. Na vida as coisas sempre acontecem nos planos físico e metafísico, quer queiramos ou não; quer acreditemos ou não. Por isso, hei de compreender que alguns não darão crédito ou crença para esta sincera e verídica história que contarei, mas as coisas assim acontecem, quer acreditemos ou não.

Estava eu na mui digna e bela cidade de Flores do Além Mar, na Província de Três Sóis,e caminhando por um campo florido ouvi sons conhecidos. Guiei-me pelo ouvido e logo cheguei na fonte dos sons. Não me espantei com o que vi, visto que creio nas coisas metafísicas e surreais. Sobre uma rosa vermelha havia 2 Borboletas dançando um pagode do tipo "dig ,dig ê; dig,dig ê "e " não era amor, não era! Era cilada, cilada,cilada ". Havia um pequeno radinho na rosa ao lado, bem como latinhas de cerveja com canudinhos enfiados.

As ditas Borboletas ignoraram minha presença, talvez por não crerem que um humano estivesse realmente vendo o que estavam fazendo.

Mais à frente, sobre uma rosa amarela, 2 Borboletas curtiam um Heavy metal alucinado, o qual não consegui identificar nenhuma palavra da cantoria. Elas batiam freneticamente suas asas, e faziam pequenas paradas para cheirarem pequenos cogumelos (provavelmente eram cogumelos alucinogénos e psicodélicos). As Borboletas se entreolhavam e diziam:

— É metal, mano. Hu,hu Baby! Iron Maiden e Sepultura forever.

As ditas Borboletas também ignoraram minha infame presença.

A distância entre as Borboletas do metal e as do pagode era curta, o que logo gerou animosidades.

- Baixa essa porra desse pagode aí, suas tontas- disseram as Borboletas do metal.

— Os incômodados que se mudem. Nem de noiados gostamos- disseram as Borboletas do pagode.

— Noiados é a pqp! O som de vocês é subcultura- disseram as Borboletas do metal.

\footnotetext{
${ }^{1}$ E-mail: marceloo.roocha@gmail.com
} 
- Subcultura um caralho! Pagode é cara e raiz. E quer saber, nem vamos mais dar confiança pra cheiradores de cogumelos. Esses noiados não sabem nem se tão acordados — disseram as Borboletas pagodeiras.

- Vão se catar suas faveladas - disseram as Borboletas metaleiras.

Aí a coisa explodiu, e se engalfinharam numa briga borboletal. As 4 formaram um bolo só, e tome bater asas e empurrões.

- É metal, porra!

-É pagode, caralho!

- Faveladas!

— Noiados alienados!

E assim seguiu-se a briga até que de repente começaram a ouvir um sonzinho baixinho e agudinho de uma viola que parecia reproduzir ventos simbilando na madrugada.

- Que porra de música é essa? - disseram as Borboletas metaleiras.

- Também estamos achando estranho- disseram as Borboletas pagodeiras.

Seguiram o som e logo viram uma Borboleta tocando uma violinha tímida nas notas,mas decidida no ímpeto. Ela estava sentada numa pedra às margens de um plácido rio. Sobre as notas baixinhas ela cantava assim:

Borboletim

Bobimbim

É tudo tão bonitinho

Se cantamos assim...

— Que merda de música é essa? — disseram as Borboletas metaleiras.

- Que troço de som esquisito - disseram as Borboletas pagodeiras.

- Meus caros, isso é a Bossa nova floral. O Som mais sofisticado da atualidade. Respeitem! — disse a Borboleta violeira.

— Sofisticado? Haha. Isso é som de burguês esnobe. Sofisticado é o metal, porra!

- Concordamos que esse troço não tem nada de sofisticado. Sofisticação tem o pagode; pois tem ritmo, balanço e harmonia - disseram as pagodeiras.

- Seja pagode ou Bossa nova floral, ambos são uma merda — disseram as Borboletas metaleiras.

- Se manquem seus noiados — disseram as Borboletas pagodeiras.

— Ei, silêncio! Vocês não têm capacidade para entenderem a maravilha que é a Bossa nova floral. É um som angelical, cultural e transcendental - disse a Borboleta violeira.

- Se tocar essa merda de novo vai ter peia- disseram as metaleiras. 
A violeira não se intimodou e começou a dedilhar novamente a sua melodia simbilante.

E lá vamos nós de novo. Agora 5 Borboletas se engalfinharam, e tome bater asas e empurrões, e lá se vai a viola voando, voando. Mas alguém agarrou-a, e logo esbravejou com voz de trovão:

- Que zona é essa? Soltem minha Professora.

As metaleiras e pagodeiras reconheceram logo de quem era a voz. Era do temido Gafanhoto Tobias, e bem sabiam que ele as devoraria com facilidade. Saltaram pra trás, e ficaram tremendo de medo.

— É isso mesmo, a Borboleta Maribel está me ensinando a tocar e cantar a Bossa nova floral. Ela tem sido uma ótima Professora. Se vocês a incomodarem de novo, vão virar meu lanche.

Nesse instante a falsidade humana se transporta para as Borboletas metaleiras e pagodeiras (como bem disse no início, os animais acabam absorvendo coisas humanas e viceversa), e logo dizem para o Gafanhoto:

- A gente tava só brincando com a Maribel. Adoramos a Bossa nova floral. É um som muito sofisticado. Íamos até pedir pra ela nos ensinar também.

- Criaturas mentirosas e fingidas. Sei que o negócio de vocês é pagode e metal disse o Gafanhoto Tobias.

- Maribel, toca nossa Bossa nova floral que essas 4 vão passar a tarde toda cantando comigo.

Maribel dedilhou o agudinho simbilante, e o Gafanhoto e as 4 Borboletas fizeram um lindo corinho:

Borboletim

Bombimbim

É tudo tão bonitim

Quando cantamos assim

Borboletim

Bombimbim.... 